\title{
Aquoeous Extract of Neem Leaves (Azadirachta Indica) Decrease Expression of Immunoglbulin E (IgE) and Interleukin 4 (IL-4) in Gingiva Tissue of BALB/c Mice Injected by Ovalbumine
}

| Dewa Ayu Ratna Dewanti ${ }^{1}$, | Dewa Ayu Susilawati², Pujiana Endah Lestari³ Roedy Budirahardjo ${ }^{4}$, Erawati Wulandari 5 , Ristya Widi ${ }^{6}$, and Sunlip Wibisono ${ }^{7}$

1Department of Biomedical Science

1,2,3 Department of Pedodontia

${ }^{4}$ Department of Dental Conservative

${ }^{5}$ Department of Public Dental Health

${ }^{6}$ Faculty of Dentistry. Department of Statistic, Faculty of Economic and Busines

7 Jember University. Indonesia

\section{Abstract}

Corresponding Author: I Dewa Ayu Ratna Dewanti idewadewanti@yahoo.com

Received: 03 October 2017 Accepted: 10 October 2017 Published: 29 November 2017

Publishing services provided by Knowledge E

(a) I Dewa Ayu Ratna Dewanti et al. This article is distributed under the terms of the Creative Commons Attribution License, which permits unrestricted use and redistribution provided that the original author and source are credited.

Selection and Peer-review under the responsibility of the VMIC Conference Committee.
Introduction. Allergy has been such a difficult disease to cure. Some anti-allergic drugs on the market caused side effects such as dryness of mucous membranes, confusion, dizziness, dry mouth, constipation, difficulty urinating and blurred vision, bull neck and moon face. It is difficult to find anti-allergic drugs with minimum side effects. Aim. The research aimed to find alternative anti-alergic agent, it was aquoeous extract of Neem leaves. In particular, this study analysed modulation of aquoeous extract of Neem leaves to expression of $\mathrm{E}$ and IL-4 in gingival tissue. Materials and Methods. A total 15 BALB/c Mice was divided into three groups, i.e controle group (no treatment were introduced), Ova group (On days 0, 7, 14 submucous injected with ovalbumine), Neem group (were given with aquoeous extract of Neem leaves $200 \mathrm{mg} / \mathrm{day} / \mathrm{kg}$ body wieght and injected with ova). Ova injection was $25 \mu \mathrm{L}$ (in $2 \mathrm{mg} / \mathrm{mL}$ PBS), while neem leaves extract were given by oral sondation. IgE and IL-4 were analysed in gingival tissue on day 21 by imunohistochemistry method. Parameters are amouts of leucocytes that expressed IgE and IL-4. Results. ANOVA and LSD test showed that aquoeous extract of Neem leaves could decrease IgE and IL-4 expression significantly $(p<0,05)$ in gingival tissue. Conclusion. Aquoeous extract of Neem leaves could be used as an alternative for anti-alergic agent.

Keywords: Aquoeous Extract from Neem Leaves; Azadirachta Indica; Ig E; IL-4; ovalbumine; oral.

\section{G OPEN ACCESS}




\section{Introduction}

Until now allergy is a disease that is difficult to overcome, which in the oral cavity often cause difficulty chewing, swallowing, causing weight loss. Allergy drugs on the market cause side effects such as dryness of mucous membranes, confusion, dizziness, dry mouth, constipation, difficulty urinating and blurred vision, bull neck, moon face. World Allergy Organization (WAO) said $22 \%$ of world population suffers from allergies. Allergens can enter the body through the respiratory tract, injections and food, where food allergy is caused high levels of protein in the diet (food allergy prevalence in Indonesia is 11-15\%).[1] As one of the meals had higher levels of protein are eggs, especially ovalbumin, in which one of the immune response that is important is $\mathrm{E}$ and IL-4. It also has been shown by research IgE levels in mice exposed ovalbumin.[25] Problems that arise and has not been solved to date is not yet found a cure for allergies with effect minimum side. Therefore, it needs proper handling solutions allergies, with therapies that have minimal side effects. One of them with herbs such as neem.

Empirically, people have been utilizing the neem plant to cope with various diseases, such as intestinal worms, scabies, malaria, fungal infections, and allergies overcome tumor. Neem (Azadirachta indica Juss) with bioactive components among others azadirachtin, milentriol, salanin, nimbin, catechin, epicatechin, galic acid, nimbidin, gedunin, trisulfida, tetrasulfida. Parts of plants are most often used as a traditional medicine are the leaves and seeds.[6-11] Although there are studies that isolate the neem plant components and proved that azadirachtin, meliantriole, salanin, nimbin, nimbidin a toxic component, but the use of neem to chemotherapy with an appropriate dose will not berbahaya. [12-15] neem modulate PMN, macrophages, lymphocytes affect phagocytic activity, TNF - $\alpha$, IFN- $y$, the activity of macrophages and immunoglobulins. From this it is alleged that the neem modulate innate immunity, cellular can humoral.[14-20]

Several studies that prove the immunomodulatory effects of neem among others, can modulate the cellular and humoral immune responses in mice immunized with ovalbumin. Modulation of the humoral immune response includes an increase in the level of g G, M. M.21] immunomodulatory potential of neem leaves extract against CD4, CD8 cell Th 1, TNF- $\alpha$, IFN $\gamma$ and macrophages in mice and primates.[22] Previous studies have proved that the author The Increasing of Macrophage CD14 Expression on Wistar Rats Fed with Aqueous Extract From Neem (Azadirachta Indica) Leaves and Inoculated by Candida albicans.[23] Moreover, the authors also proved Neem Leaves (Azadirachta Indica) Improve Oral Mucosa Defense Mechanism Againts Candida 
Albicans [24]. Besides, the author also has proving Neem Leaves (Azadirachta Indica): One of Solution to Overcome Allergic Reaction in Oral [25]. Increased TLR4 expression on macrophages in the oral cavity Wistar rats were given Consumption of Liquid Leaf Extract Neem (Azadirachta indica).[26] TNF- $\alpha$ expression on rats after Candida albicans inoculation and neem (Azardirachta indica) extract feeding.[25] Phagocytic Activity Machropage to Candida albicans.[25] This phenomenon indicates that neem can modulate the immune response, thus alleged that neem leaves can improve the immune system.

\section{Materials And Methods}

Materials used in this study include: BALB/c mice young adults (1-2 months old), males, 100-200 g (weighing the same or not much different, pre-treated weighed), liquid extract of neem leaves, ovalbumin, PBS, rat anti-mouse lg E (Dako), Imunostaining KIT (Dako), xylol, absolute ethanol, trypsin 0.025\%, $\mathrm{H}_{2} \mathrm{O}_{2}$, Meyer-HE. equipment used in this study include sonde, spatula cement, excavators, glass plate, plastic filling instrument, tweezers, scissor, measuring cup, blade and scalpel, mask, gloves, stopper cement, fissure bur cylindrical no.3, Dental specialty chair mice, cotton pellets, bimokuler microscope (Olympus, USA), autoclave, vibrator, microtomes, object of glass and glass deck, humidity chamber.

A total $15 \mathrm{BALB} / \mathrm{c}$ Mice was divided into three groups, i.e controle group (no treatment were introduced), Ova group (submucous injected with ovalbumine), Neem group (were given with aquoeous extract of Neem leaves $200 \mathrm{mg} /$ day/kg body wieght and injected with ova). Ova injection was $25 \mu \mathrm{L}$ (in $2 \mathrm{mg} / \mathrm{mL}$ PBS) On days $0,7,14,[4]$ while neem leaves extract were given by oral sondation. IgE and IL-4 were analysed in gingival tissue after 7 days treatment by means of imunohistochemistry method. Mixture done 3 times deparanisasi use xylol, xylol eliminated with absolute ethanol ranging up to $70 \%$, the last with water, washed with $\mathrm{PBS} \mathrm{pH}$ 7.4. To remove debris by trypsin $0.025 \%$. Mixture flooded $3 \% \mathrm{H}_{2} \mathrm{O}_{2}$ solution for 10 minutes. Washed $2 \mathrm{x}$ PBS and blocking process is carried out with $3 \%$ BSA for 10 minutes. Reacted with the antibody IgE (Dako) was incubated for 24 hours at a temperature of $40 \mathrm{C}$ in a humidity chamber. Biotiyilized reacted with secondary Ab (rat anti-mouse g E, Dako) for 1 hour. Washed 3 times with PBS each 5 minutes, then added peroxidase labeled streptavidin and incubated for 1 hour. Washed 3 times with PBS, then treated with DAB (Dako) substrate created a new and incubated for approximately 30 minutes at room temperature with shaken. Washed with distilled water, added Meyer-HE for 10 minutes. Washed with tap water, then with distilled water. Dried preparations, spilled 


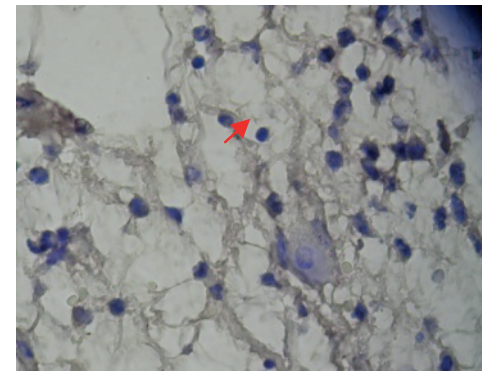

Controle Groups

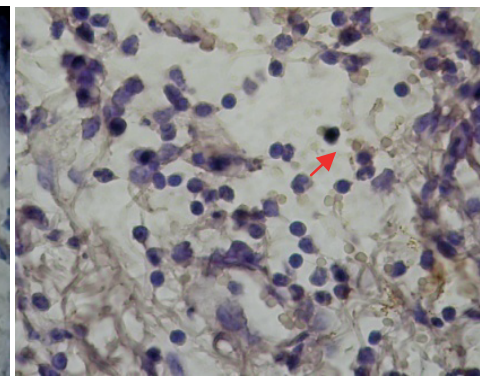

ova Groups

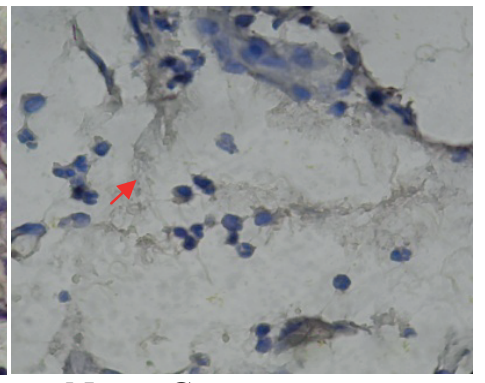

Neem Groups

Figure 1: Expression of IgE (arrow) in gingival tissue BALB / $\mathrm{c}$ mice that were gien by aquoeous extract of Neem leaves (magnification $400 \mathrm{x}$ ).

entelan and covered with a coverglass. Parameters are amouts of leucocytes that expressed IgE and IL-4. Data were analyzed by descriptive, ANOVA followed by LSD test.

\section{Results}

The results of descriptive analysis showed decreased expression of IgE and IL-4 intra and extra cells. Express of IgE and IL-4 showed an increase in the group injected with ovalbumin. While neem leaves aqueous extract can decrease the number of leucocytes that express IgE and IL-4, as seen in the neem extract at a dose of $200 \mathrm{mg} /$ day/BB has been a decline in the number of IgE, IL-4 expression. The research data have been obtained subsequently analyzed using one-way ANOVA result there are significant differences. Figure 2, the expression of IgE, IL-4 indicate average almost the same, except ova goups showed the highest expression, whereas neem groups visible IgE, IL-4 expression decreased.

Note:

Leukocytes membrane surrounded by brown color was expression of I E or IL-4 (red arrow), whereas it was not surrounded by brown color was not expression of g E or IL-4 (white arrow).

\section{Discussion}

IgE, IL-4 expression in gingiva tissue in the group exposed by neem leaves aqueous extract showed a decrease compared with the group that was exposed only ova and control. It appears that aquoeous extract of Neem leaves to cure with the decrease as a result of exposure to allergens ova. aquoeous extract of Neem leaves consumed will be quickly distributed throughout the body, including to the oral mucosa. Aqueous extracts 


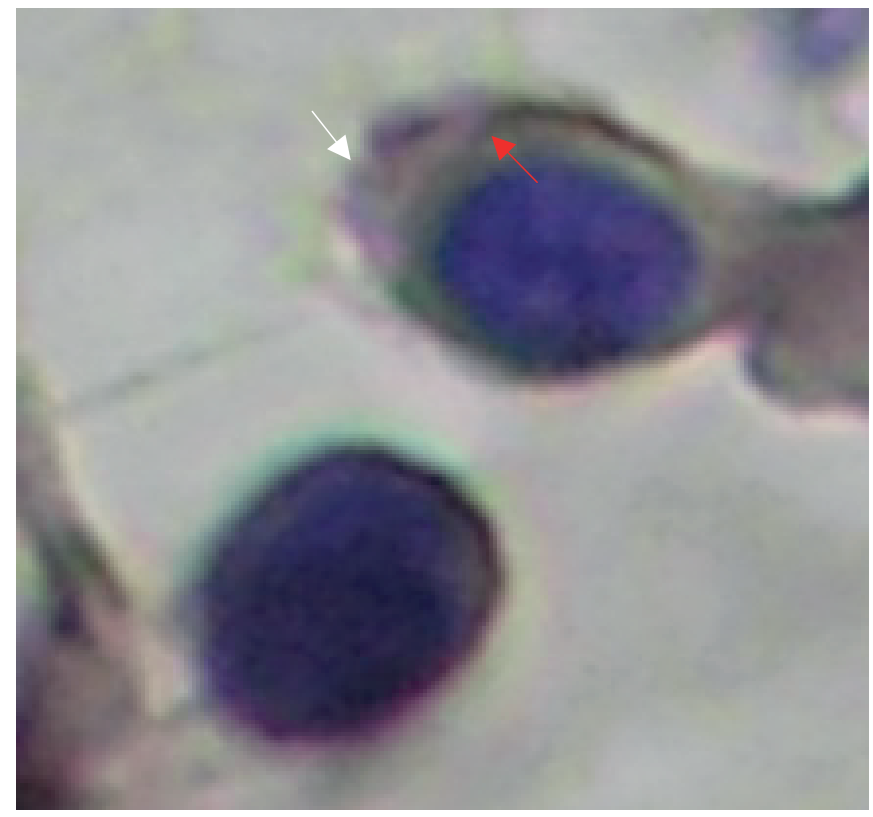

Figure 2: IgE or IL-4 expression in the zoom.

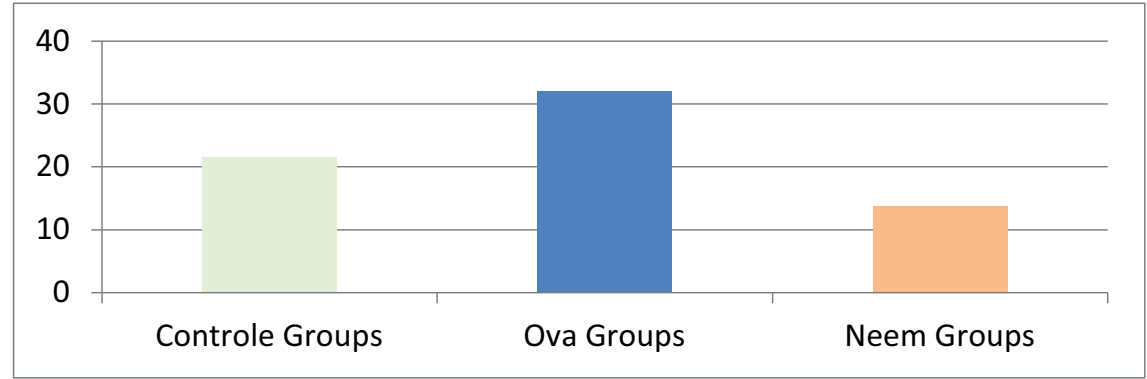

Figure 3: The bar chart IgE expression by the research group.

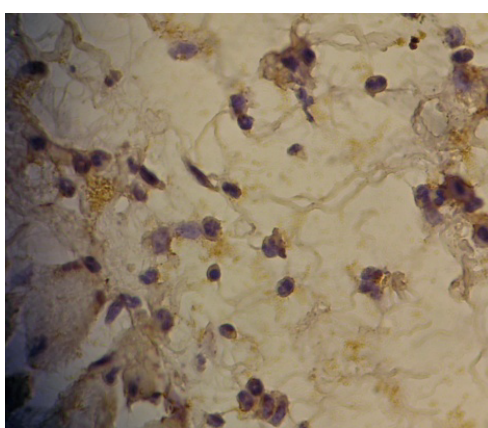

Controle Groups

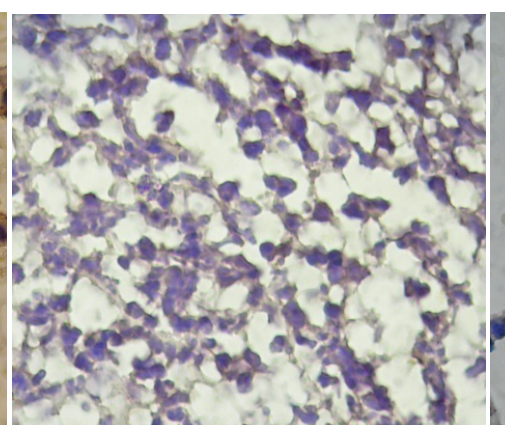

ova Groups

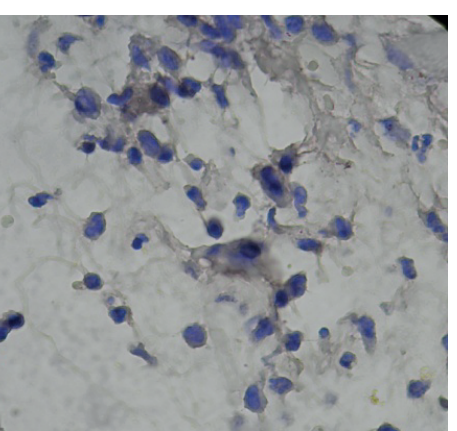

Neem Groups

Figure 4: Expression of IL-4 (arrow) in gingival tissue BALB / c mice that were given by aquoeous extract of Neem leaves (magnification $400 \mathrm{x}$ ).

of neem leaves with the content of galic acid, catechin, epicatechin may affect the immune response, presumably through two ways, that affect ova and directly affect the immune response. The effect on the ova is thought to cause changes in the ova, so the ova is not an allergen again to the body, while the immune response is expected 


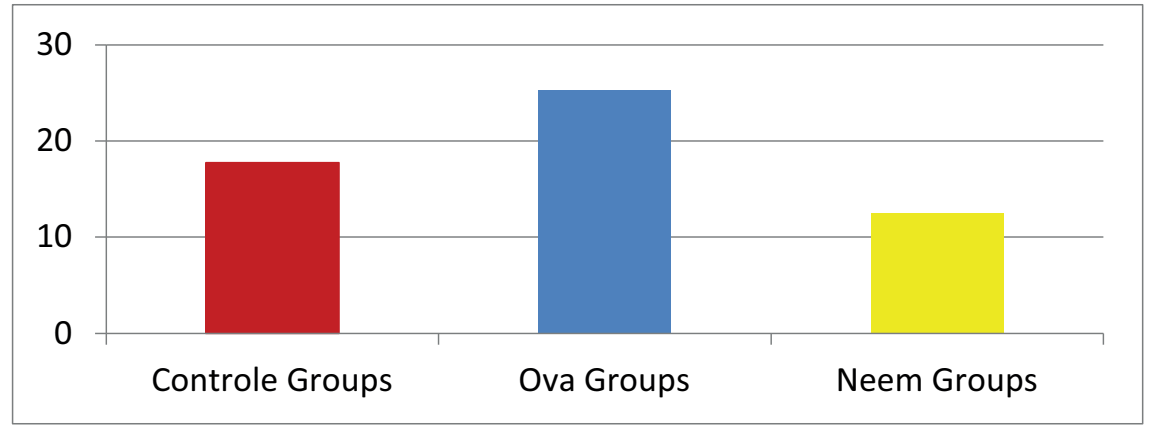

Figure 5: The bar chart IL-4 expression by the research group.

to affect the APC (Antigen Precenting Cells)) in recognizing allergens (cell activity was decreased/unresponsive to allergens).

Production of IL-10 or TGF- $\beta$ by Treg will affect B cells in producing IgE, IgG, IgA. Th2 function to produce IL- 4 which affects the production of IgE by B cells, IL-5, which affects the activity of eosinophils. Th1 that play a role in the production of IFN- $\gamma$ is also inhibited. Constraints on all these activities will affect allergic responses to decrease. Can be described blocking production of IL-10 will inhibit the activity of mast cells, eosinophils, B cells, Treg and Th2. Decreasing of IgE, IL-4 expression in gingiva, the expected clinical symptoms due to allergic reactions have also decreased (in this study were not observed clinical symptoms appear). Therefore, to further research needs be observed all the components associated with allergic reactions, such as mast cells, basophils, eosinophils, another cytokines as well as clinical symptoms are useful to uncover more roles extract neem leaves liquid on the prevention and treatment of allergy, especially in the oral cavity.

\section{Conclusion}

Aquoeous extract of Neem leaves decreased the expression of IgE, IL-4 gingiva of BALB / c mice were exposed to ovalbumin. So, Aquoeous extract of Neem leaves could be used as an alternative for anti-alergic agent.

\section{Acknowledgements}

A big thank you to Research University of Jember which gives an opportunity to obtain research grants and RISTEK DIKTI which has provided funding for this study. 


\section{References}

[1] Baratawidjaja, Karnen G. 2006. Imunologi Dasar. Ed. 7. Jakarta: Balai Penerbit FKUI.

[2] J.C.S. Saldanha, D.L. Gargiulo, S.S. Silva, F.H. Carmo-Pinto, M.C. Andrade, J.I. AlvarezLeite, M.M. Teixeiraand D.C. Cara. A model of chronic IgE-mediated food allergy in ovalbumin-sensitized mice. Braz J Med Biol Res, June 2004, Vol 37(6) 809-816.

[3] Caskill Mc. A C, C S Hosking, and D J Hill. Anaphylaxis following intranasal challenge of mice sensitized with ovalbumin. J. Immunology. 1984 April; 51(4): 669-677.

[4] Sun L.-Z, S. Elsayed, T. B. Aasen, T. Van Do, N. P. Aardal, E. Florvaag, K. Vaali. 2010. Comparison between Ovalbumin and Ovalbumin Peptide 323-339 Responses in Allergic Mice: Humoral and Cellular Aspects. Scandinavian Jpurnal of Immunology, Volume 71, Issue $5:$ 329-335.

[5] Till SJ ${ }^{1}$, Francis JN, Nouri-Aria K, Durham SR. Mechanisms of immunotherapy. J Allergy Clin Immunol. 2004 Jun;113(6):1025-34.

[6] Ganguli S, 2002, Jun. Neem : A therapeutic for all seasons. Current Science.;82(11).

[7] Goel RK, K. Sairam, 2002. Anti ulcer drugs from indigenous source with emphasis on musa sapientum, tamrabhasma, asparagus recemous and zingiber officinale. Indian J of Pharamacology; vol.34:100-110.

[8] Helmy A. Wafaa, Hassan Amer and Nefisa M.A. El-Shayeb, 2007. Biological and Antimicrobial Activity of Aquoeus Extracts from Neem tree (Azdirachta Indica A. Juss, Meliaceace). Journal of Applied Sciences Research, 3(10):1050-1055.

[9] Dang Minh Nguyen, jean-Pierre Julien and Serve Rivest, 2002. The family of and pro- inflammtory signal-transduction pathways that recruit $\mathrm{NF}_{-K} \mathrm{~B}$. Nature Reviews Neurosceience 3; March;216-227.

[10] Atangwho I. J., P. E. Ebong, E. U. Eyong, I. O. Williams, M. U. Eteng and G. E. Egbung, 2009. Comparative Chemical Composition of Leaves of Some Antidiabetic Medicinal Plants: Azadirachta indica, Vernonia amygdalina and Gongronema latifolium. African Journal of Biotechnology Vol. 8 (18), pp. 4685-4689.

[11] Biswas K, Ishita C, Ranajit KB and Uday Bandyopadhayay, June 2002. Biological activities and medical properties of neem (Azadirachta Indica). Current Science, vol. 82 , No. 11:1336-1345.

[12] Okemo, P.O Mwatha, E.W,and Chhabra, S.C, 1998. Antibacterial activity of plant extracts. A comparison of agar dilution and microtitre broth dilution methods. Discoveries and Innovation, 10(1/2):111-115.

[13] Okemo, P.O Mwatha, and Ngigi, S.K, 1999. Activity of some medicinal plant pathogens. East Africa Journal of Science, 1(2):1-7. 
[14] Upadhayay Dhawan S, Garg S, Talwar GP, 1992, Oct. Immunomodulation effect of neem Azadirachta Indica oil. Int J immunopharmacol.; vol.14(7)L1187-93

[15] SaiRam, Sharma SK, Havazhagan G, Kumar D, Selavamurthy W., 1997 Jan. Immunomodulatory effect of NIM-76, a volatile fraction from Neem oil. J Ethnopharmacol.;vol.55(2):133-9.

[16] Sairam. G. Havazhagan, S.K Sharma, S.A Dhanraj, B. Suresh, M.M. Parida A.M. Jana, Kumar Devendra, W. Selvamurthy, 2000 August. Journal of Ethnopharmacology.; vol.71(3);377-382.

[17] Sastrodiharjo, S., 1988. Evaluasi Daya Insektisida Dari Ekstrak Daun Mimba (Azadirachta indica A. Juss). Seminar Hasil Penelitian Pangan dan Gizi, Ilmu Hayati, 17 PAU: Jakarta.

[18] Sedekar, Kolte AY, Barnase BS Desai VF, 1998 Nov. Immunolpotentiating effects of Azadirachta Indica (Neem) dry leaves powder in broilers, naturally infected with IBD virus. Indian J Exp Biol.;vol.36(11);1151-3.

[19] Ray, Banerjee BD, Sen P, 1996 Jul. Modulation of hmoral and cell-mediated immune responses by Azadirachta Indica (Neem) in mice. Indian J Exp Biol.;vol.34(7):698701.

[20] Talwar, Shah S, Muhkerjee S, Chabra R, 1997 Jun. Induced termination of pregnancy by purified extracts of Azadirachta Indica (Neem):mechanism involved. Am J Reprod Immunol.;vol.37(6);485-91.

[21] Dewanti Ratna, 2003. 5th FDI-IDA JOINT MEETING Bali International Hi-Tech Dental Exhibition 2009: "The Increasing of Macrophage CD14 Expression on Wistar Rats Fed with Aqueous Extract From Neem (Azadirachta Indica) Leaves and Inoculated by Candida albicans"

[22] Dewanti Ratna. 6th FDI-IDA JOINT MEETING Balikpapan International Dental Exhibition tanggal 12-14 Nopember 2010: "Neem Leaves (Azadirachta Indica) Improve Oral Mucosa Defense Mechanism Againts Candida Albicans".

[23] Dewanti Ratna, 7th FDI-IDA JOINT MEETING Semarang Dental Exhibition 2011 "New Horizons in Indonesian Oral Health Care. "Neem Leaves (Azadirachta Indica): One of Solution to Overcome Allergic Reaction in Oral"

[24] Program Abstracts P1-6. Dewanti Ratna, 15-16 Oktober 2010. "Increased TLR4 expression on macrophages in the oral cavity Wistar rats were given Consumption of Liquid Leaf Extract Neem (Azadirachta indica). "Dentisphere. di Uiversitas Hang Tuah Surabaya. preceeding Seminar. hal. 27.

[25] Dewanti Ratna.1 Maret 2011. " TNF- $\alpha$ expression on rats after Candida albicans inoculation and neem (Azardirachta indica) extract feeding". Dental Journal Majalah 
Kedokteran Gigi. ISSN: 1978-3728 Terakreditasi No. 83/DIKTI/Kep./2009. Vol. 44(1):49-53.

[26] Dewanti Ratna, 1-3 March 2012. The 2nd International Joint Symposium on Oral and Dental Sciences in Conjuction with Dental Specialists Seminar". ISBN: 978-6029461-16-9 dengan judul "Phagocytic Activity Machropage to Candida albicans". 